\title{
Organoleptik Ayam Broiler Melalui Penggunaan Tepung Krokot (Portulaca oleracea L) yang Disubtitusikan dalam Ransum Komersial
}

\author{
Organoleptic Broiler Through the Use of Purslane Flour (Portulaca oleracea L) \\ Subtituted in Commercial feed
}

\author{
M. E. Manafe dan M. L. Ressie \\ Balai Besar Pelatihan Peternakan Kupang, Nusa Tenggara Timur \\ Corresponding e-mail : menixetwan@gmail.com
}

\begin{abstract}
The objectives of this research was study the effect and level of using pursland flour (Portulaca oleracea L) which was substituted in broiler feed to color, aroma and taste by National Animal Husbandry Training Centre Kupang. The experimental used was Completely Randomizet Block Design (CRBD) with 4 (four) treatments, 5 (five) block and 5 (five) replication, each replication consist of 5 (five) broilers, so the total of the broiler were 100 heads. The treatments were KR $0=$ commercial feed without purslane flour, KR5 = commercial feed contained $5 \%$ purslane flour, KR10 $=$ commercial feed contained $10 \%$ purslane flour and KR15 $=$ commercial feed contained $15 \%$ purslane flour. Parameters meansured were color, aroma and taste. Data were analyzed using Analysis of Variance (ANOVA). The results of the study showed that the use of purslane flour in broiler feed had an effect taste but had no effect to color and aroma. To be concluded that using purslane flour (Portulaca oleracea L) in broiler commercial feed up to $15 \%$ can be used to improve organoleptic of broiler chicken meat.
\end{abstract}

Key words : broiler, puslane flour, organoleptic

\begin{abstract}
ABSTRAK
Penelitian ini dengan tujuan mengetahui pengaruh dan level penggunaan tepung krokot (Portulaca oleracea L) dalam ransum terhadap warna, aroma dan cita rasa daging ayam broiler, telah dilakukan di kandang ayam Balai Besar Pelatihan Peternakan Kupang. Rancangan yang digunakan adalah Rancangan Acak Lengkap Berblok (RAL B) yang terdiri dari 4 perlakuan, 5 blok dan 5 ulangan dengan masing-masing ulangan sebanyak 5 ekor sehingga total ayam adalah 100 ekor. Perlakuan tersebut yaitu KR0 $=$ ransum komersial tanpa tepung krokot, KR5 = ransum komersial yang mengandung 5\% tepung krokot, KR10 = ransum komersial yang mengandung $10 \%$ tepung krokot dan KR15 = ransum komersial yang mengandung $15 \%$ tepung krokot. Parameter yang diukur adalah warna, aroma dan cita rasa daging. Data yang diperoleh dianalisis menggunakan Analysis of Variance (ANOVA). Hasil penelitian menunjukkan bahwa penggunaan tepung krokot dalam ransum berpengaruh terhadap cita rasa daging tetapi tidak berpengaruh terhadap warna dan aroma daging. Disimpulkan bahwa penggunaan krokot dalam ransum komersial ayam broiler sampai dengan level 15\% dapat dimanfaatkan untuk meningkatkan organoleptik daging ayam broiler.
\end{abstract}

Kata kunci : Ayam broiler, Tepung krokot, organoleptik

\section{PENDAHULUAN}

Pertumbuhan ayam broiler yang cepat akan disertai dengan penimbunan lemak yang tinggi pula (Atmomarsono, 2004). Perlemakan yang tinggi membuat sebagian masyarakat enggan menerima produk broiler ini, karena ketakutan akan timbulnya kegemukan dan gangguan penyakit jantung (Syahruddin, 2000). Peningkatan kualitas produk perlu dilakukan untuk mengatasi masalah tersebut yaitu dengan mengurangi kandungan lemak dan kolesterol daging ayam broiler serta dapat mempertahankan organoleptik daging ayam dengan memanfaatkan sumber daya lokal sebagai alternative bahan pakan ternak dalam pemeliharaan ayam broiler sekaligus dapat menekan biaya pakan.

Jenis tumbuhan krokot (Portulaca oleracea $L$ ) lebih banyak ditemukan di Indonesia dibandingkan sumber tanaman yang lain. Rashed et al., (2004) menyatakan bahwa tumbuhan krokot mengandung komponen asam lemak omega-3 tertinggi diantara sayuran lain dan mengandung xanthophyl, ß-carotene, folic acid, vitamin $\mathrm{C}$, kalium, kalsium dan berfungsi sebagai antioksidan (Irawan et al., 2003). Tumbuhan 
krokot segar mengandung asam lemak omega-3 sebesar $400 \mathrm{mg} / 100 \mathrm{~g}$, alpha-tocopherol 12,2 $\mathrm{mg} / 100 \mathrm{~g}$, and ascorbic acid $26,6 \mathrm{mg}$; betacarotene 1,9 mg dan glutathione 14,8 mg (Uddin et al., 2014).

Asam lemak omega-3 dapat ditemukan pada sumber hewani seperti tepung ikan dan minyak ikan akan tetapi penggunaan bahan-bahan tersebut mempunyai respon negatif terhadap kualitas sensori telur, seperti berbau amis ikan (Bou et al., 2005). Oleh karena itu, perlu adanya alternatif lain yaitu dengan penambahan asam lemak omega-3 yang berasal dari tanaman seperti flaxseed oil (Kartikasari et al., 2012), canola oil (Rowghani et al., 2007), hempseed oil (Goldberg et al., 2012) dan purslane (Evaris et al., 2015).

Kandungan asam lemak omega-3 dalam karkas atau daging dapat ditingkatkan melalui manipulasi pakan (kartikasari et al., 2012). Laporan Mullik et al. (2015) dan Tulanggalu, et al., (2017) menyatakan bahwa dengan menambahkan tepung krokot (Portulaca oleracea L) dalam ransum ayam pada level $2,5 \%, 5 \%$ dan $7,5 \%$ tidak memberikan pengaruh terhadap $\mathrm{pH}$ daging namun memberikan pengaruh yang nyata terhadap daya ikat air, susut masak dan keempukan daging ayam broiler. Kartikasari et al., (2018) juga melaporkan hal yang sama bahwa pakan ayam yang diperkaya dengan tepung krokot (Portulaca oleracea L) hingga level 12\% tidak mengubah kualitas daging termasuk $\mathrm{pH}$, WHC, keempukan, kadar air dan kadar lemak. Selanjutnya dilaporkan Mullik et al. (2015) bahwa krokot yang digunakan masih dalam bentuk mash dan metode pencampuran pakan komersial dan tepung krokot yang belum tepat sehingga ada kemungkinan tepung krokot yang diberikan tidak terkonsumsi secara maksimal oleh ternak ayam. Sejauh ini penggunaan tepung krokot sebagai pakan dalam mempertahankan dan meningkatkan organoleptik baik warna, aroma dan cita rasa pada daging ayam broiler masih terbatas dan belum banyak dilaporkan.

Oleh karena itu perlu dilakukan suatu penelitian dengan meningkatkan level krokot dan menggunakan pakan pellet yang disubtitusikan dalam ransum komersial sehingga pemanfaatan tumbuhan krokot ini diharapkan dapat meningkatkan kualitas organoleptik daging ayam broiler dan bermafaat bagi kesehatan manusia.

\section{MATERI DAN METODE}

Penelitian ini telah dilaksanakan selama 6 minggu yaitu 1 (satu) minggu penyesuaian dan 5 (lima) minggu pengambilan data bertempat di kandang ayam potong Balai Besar Pelatihan Peternakan (BBPP) Kupang Desa Noelbaki Kecamatan Kupang Tengah - Kabupaten Kupang. Materi Penelitian yang digunakan dalam penelitian ini adalah ayam broiler strain CP 707 sebanyak 100 ekor yang dipelihara selama 6 minggu (umur 42 hari). Ayam yang dipelihara ditempatkan dalam petak kandang postal system litter berukuran $120 \times 60 \times 50 \mathrm{~cm}$. kandang petak tersebut berjumlah 20 unit dengan masing-masing petak berisi 5 ekor DOC. Peralatan yang digunakan dalam penelitian ini berupa tempat pakan dan tempat air minum, tirai penutup, brooder, kertas koran, lampu, termos es, plastik klip, plastik polietilena, ember, mesin penepung dan mesin pencetak pellet. Peralatan untuk mengukur peubah berupa timbangan digital kapasitas $5 \mathrm{~kg}$, gelas ukur, label, plastik, termometer, sarung tangan dan peralatan laboratorium. Bahan yang digunakan adalah tepung krokot, ransum komersial CP-11 untuk fase starter (minggu 1-3) dan CP-12 untuk fase finisher (minggu 4-6).

Tabel 1. Komposisi kimia tepung krokot, pakan komplit CP-11 dan CP-12 produksi PT Chaeron Pokphand Indonesia

\begin{tabular}{lccc}
\hline \multicolumn{1}{c}{ Komposisi Kimia } & Tepung krokot & CP-11 & CP-12 \\
\hline Bahan Kering (\% segar) & 10,00 & - & - \\
Bahan Kering (\%) & 93,66 & 92,36 & 93,54 \\
Air (\%) & 6,34 & 7,64 & 6,46 \\
Abu (\%BK) & 7,51 & 7,46 & 7,48 \\
Bahan Organik (\%BK) & 86,15 & 84,90 & 86,06 \\
Protein Kasar (\%BK) & 14,77 & 17,65 & 16,26 \\
Lemak Kasar (\%BK) & 1,80 & 2,66 & 4,40 \\
Serat Kasar (\%BK) & 14,53 & 3,73 & 5,11 \\
Karbohidrat (\%BK) & 69,58 & 64,58 & 65,41 \\
Bahan Extrat Tanpa Nitrogen (\%BK) & 55,05 & 60,85 & 60,30 \\
\hline
\end{tabular}

Sumber : * Hasil Analisis Laboratorium Nutrisi dan Pakan Ternak Politeknik Pertanian Negeri Kupang (2017). 
Ransum perlakuan dalam bentuk pellet penggabungan antara ransum komersial dengan tepung krokot pada level yang berbeda ; $5 \%, 10$ $\%$ dan $15 \%$ disesuaikan kebutuhan ransum ayam per ekor sampai panen. Air minum yang diberikan secara add libitum, formades, vita strong, vita chick, alkohol, daging bagian dada dari ayam broiler yang telah mendapat perlakuan pemberian tepung krokot dalam ransum.

Penelitian ini menggunakan metode experiment dengan menggunakan rancangan percobaan Rancangan Acak Lengkap Berblok (RALB) yang terdiri dari 4 perlakuan, 5 blok dan masing-masing blok terdiri dari 5 ulangan sehingga diperoleh 20 unit percobaan sehingga ternak ayam yang digunakan adalah 100 ekor. Penempatan ayam dalam kandang dilakukan secara acak.

Ransum perlakuan yang diuji terdiri dari :

KR0 : Ransum komersial tanpa tepung krokot sebagai control

KR5 : Ransum komersial mengandung 5\% tepung krokot

KR10 : Ransum komersial mengandung 10\% tepung krokot

KR15 : Ransum komersial mengandung 15\% tepung krokot

\section{Pengumpulan Data Penelitian}

Setelah ayam berumur 6 minggu, dilakukan penimbangan berat akhir, sebanyak 40 ekor ayam dipotong yang terdiri dari 10 ekor tiap perlakuan yang terbagi menjadi 2 ekor tiap unit ulangan. Selanjutnya ayam dibersihkan lalu dipisahkan jeroan dan karkas. Daging/otot dada diambil diambil sebagai sampel untuk dilakukan uji organoleptik oleh panelis di laboratorium untuk warna, aroma dan cita rasa.

\section{Variabel Penelitian}

Variabel yang diukur dan cara pengukurannya.

Warna, aroma dan cita rasa

Pengujian warna, aroma dan cita rasa daging merupakan uji organoleptik diperoleh dengan cara memberikan skor dari tertinggi sampai terendah (4-3-2-1) pada masing-masing variabel yang dilakukan oleh panelis yang memenuhi persyaratan sebanyak 9 orang. Panelis diberikan petunjuk dan dilaksanakan sesuai prosedur/instruksi.
Warna daging

Daging ayam berwarna putih keabuan dan cerah, sedangkan yang tidak baik berwarna putih pucat dan merah kehitaman atau gelap. Penentuan skor warna daging yaitu : $4=$ Putih keabuan dan cerah, $3=$ Merah kecoklatan $3=$ Merah pucat dan $1=$ Merah kebiruan.

\section{Aroma daging}

Sampel daging diambil dari setiap ulangan, kemudian dimasukkan kedalam piring dan langsung dihirup oleh Panelis untuk menentukan skor aroma. Penentuan skor aroma daging yaitu : $4=$ Berbau khas daging ayam, $3=$ Berbau daging ayam, 2 = Berbau amis, $1=$ tidak berbau.

Cita rasa

Sebelum dilakukan penilaian, daging terlebih dahulu dimasak selama 15 menit dengan suhu $80{ }^{\circ} \mathrm{C}$. Setiap Panelis mengkonsumsi 3-4 potong daging yang sudah disiapkan dari setiap perlakuan dan selanjutnya dilakukan penilaian. Skor cita rasa daging yaitu : $4=$ Sangat enak, $3=$ Enak, 2 = Kurang enak dan $1=$ Tidak enak.

\section{Analisis Data}

Data yang diperoleh ditabulasi dan dianalisis menggunakan analisis sidik ragam atau Analysis of Variance (ANOVA) dan analisis non parametrik Kruskall Wallis Test untuk melihat pengaruh perlakuan terhadap variabel yang diteliti dan untuk melihat perbedaan dilakukan dengan uji lanjut Mann-Whitney. Software yang digunakan untuk mengolah data adalah SPSS.

\section{HASIL DAN PEMBAHASAN}

Kualitas daging dipengaruhi oleh jumlah nutrisi yang terkandung dalam bahan pakan sehingga pangan yang dihasilkan enak rasanya, bernilai gizi tinggi dan aman untuk dikonsumsi. Tepung krokot merupakan salah satu bahan alternatif yang digunakan untuk menanbah zat nutrisi dalam daging. Komposisi kimia ransum penelitian yang disajikan pada tabel 2 memperlihatkan adanya perubahan persentasi pada protein kasar maupun serta kasar seiring dengan penambahan tepung krokot dalam ransum. 
Tabel 2. Komposisi kimia ransum penelitian yang mengandung tepung krokot 5\%, 10\%, dan $15 \%$ dalam pakan komersial CP-11 dan CP-12

\begin{tabular}{lrrrrrr}
\hline \multirow{2}{*}{ Komposisi Kimia } & $\begin{array}{r}\text { 5\% KR } \\
\text { CP-11 }\end{array}$ & $\begin{array}{r}\text { CP-11 } \\
\text { C KR }+\end{array}$ & $\begin{array}{r}\text { 15\% KR }+ \\
\text { CP-11 }\end{array}$ & $\begin{array}{r}5 \% \mathrm{KR} \\
+ \text { CP-12 }\end{array}$ & $\begin{array}{r}10 \% \mathrm{KR}+ \\
\text { CP-12 }\end{array}$ & $\begin{array}{c}15 \% \mathrm{KR}+ \\
\mathrm{CP}-12\end{array}$ \\
\hline Bahan Kering (\%) & 92,43 & 92,49 & 92,56 & 93,55 & 93,55 & 93,56 \\
Air (\%) & 7,57 & 7,51 & 7,44 & 6,45 & 6,45 & 6,44 \\
Abu (\%BK) & 7,46 & 7,47 & 7,47 & 7,48 & 7,48 & 7,48 \\
Bahan Organik (\%BK) & 84,96 & 85,02 & 85,09 & 86,07 & 86,07 & 86,08 \\
Protein Kasar (\%BK) & 17,51 & 17,36 & 17,22 & 16,18 & 16,11 & 16,03 \\
Lemak Kasar (\%BK) & 2,62 & 2,58 & 2,53 & 4,27 & 4,14 & 4,01 \\
Serat Kasar (\%BK) & 4,27 & 4,81 & 5,35 & 5,58 & 6,06 & 6,53 \\
Karbohidrat (\%BK) & 64,83 & 65,08 & 65,33 & 65,62 & 65,83 & 66,04 \\
Bahan Extrat Tanpa Nitrogen & 60,56 & 60,27 & 59,98 & 64,04 & 59,77 & 59,51 \\
(\%BK) & & & & & &
\end{tabular}

Sumber: * Hasil Analisis Laboratorium Nutrisi dan Pakan Ternak Politeknik Pertanian Negeri Kupang (2017).

Hasil pengujian organoleptik oleh panelis terhadap warna, aroma dan cita rasa daging disajikan pada tabel 3 memperlihatkan adanya pengaruh terhadap cita rasa namun tidak berpengaruh terhadap warna dan aroma daging berdasarkan hasil uji Kruskal-Wallis. Hasil pengujian pada tabel 3 menunjukkan bahwa penambahan tepung krokot dalam ransum sampai dengan level $15 \%$ tidak memberikan efek negatif terhadap warna, aroma dan cita rasa daging ayam.

Tabel 3. Rataan skor warna, aroma dan cita rasa daging ayam broiler yang diberikan tepung krokot.

\begin{tabular}{lcccc}
\hline \multirow{2}{*}{ Variabel } & \multicolumn{4}{c}{ Perlakuan } \\
\cline { 2 - 5 } & KR0 & KR5 & KR10 & KR15 \\
\hline Warna & 3,49 & 3,49 & 3,42 & 3,50 \\
Aroma & 3,17 & 3,17 & 3,21 & 3,10 \\
Cita rasa & 2,57 & 3,16 & 3,13 & 3,26 \\
\hline
\end{tabular}

\section{Pengaruh perlakuan terhadap warna dan aroma daging}

Warna daging yang diperlihatkan pada tabel 3 berdasarkan hasil uji Kruskal-Wallis terhadap warna daging menunjukkan tidak adanya perbedaan antara perlakuan pemberian krokot. Penilaian telah dilakukan oleh 9 (Sembilan) Panelis memberikan skor yang tidak berbeda terhadap warna yaitu rataan skor 3,42-3,50 (Merah kecoklatan menuju putih keabuan dan cerah) adalah yang terbaik. Hal ini sesuai dengan pernyataan Forrest et al., (1975), bahwa daging ayam yang normal adalah putih keabuan sampai merah pudar atau ungu. Dengan kata lain bahwa penggunaan tepung krokot dalam ransum tetap memberikan warna yang normal pada daging ayam.

Hasil uji Kruskal-Wallis terhadap aroma daging menunjukkan tidak adanya pengaruh perlakuan terhadap aroma daging yaitu pada rataan skor 3,10 - 3,21 (Berbau daging ayam) adalah dalam kategori uji aroma yang baik. Hal ini disebabkan karena komponen dalam krokot tidak berpengaruh pada aroma daging. Selain itu, kemungkinan disebabkan oleh kadar perlemakan dan umur yang tidak berbeda pada daging ayam perlakuan. Seperti yang dikemukakan Amerine et al., (1965), kadar lemak dan umur sangat mempengaruhi aroma. Aroma maupun warna daging yang baik diduga didukung oleh penanganan yang baik sehingga ternak ayam tidak mengalami stress pada saat pemotongan. Hal ini seperti yang dinyatakan Soeparno (1994), faktorfaktor yang mempengaruhi warna daging adalah pakan, spesies, bangsa, umur, jenis kelamin, stress, (tingkat aktivitas dan tipe otot), $\mathrm{pH}$ dan oksigen. Semua faktor tersebut merupakan penentu utama konsentrasi pigmen myoglobin daging (Soeparno, 1994). Pemberian krokot dalam ransum ayam broiler tidak memberikan pengaruh negatif terhadap warna dan aroma daging ayam broiler.

\section{Pengaruh perlakuan terhadap cita rasa daging}

Untuk cita rasa daging ayam broiler, hasil uji Kruskal-Wallis terhadap cita rasa daging menunjukkan adanya pengaruh perlakuan terhadap cita rasa daging yang terdeteksi secara statistik berdasarkan hasil uji lanjut MannWhitney.

Grafik perubahan cita rasa daging ayam broiler memperlihatkan bahwa kelompok ternak yang mendapat krokot $0 \%$ (KR0) berbeda dengan yang mendapat krokot $15 \%$ (KR15). Hal ini menunjukkan bahwa Panelis memberikan nilai cita rasa pada daging ayam dengan nilai modus merupakan nilai yang sering muncul dengan rataan skor $3(3,13,3,16$ dan 3,26$)$ adalah enak dan 
kelompok ternak yang mendapat krokot 15\% (KR15) adalah yang terbaik.

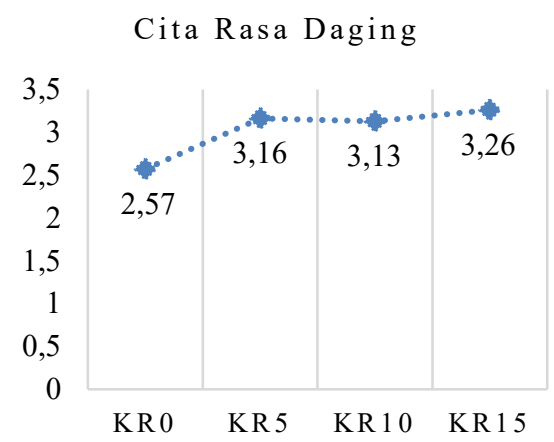

Grafik 1. Grafik perubahan cita rasa daging ayam broiler yang diberikan tepung krokot

Hal ini kemungkinan didukung oleh proses pemotongan dan pemasakan daging yang baik serta nilai susut masak yang rendah pada saat pemasakan. Susut masak berkaitan dengan kadar jus daging yang terikat di dalam dan diantara serabut otot (Soeparno, 2005). Daging dengan susut masak rendah menampilkan kualitas yang lebih baik karena kehilangan nutrisi selama pemasakan lebih sedikit. Faktor yang mempengaruhi rasa pada daging ayam broiler adalah proses pemasakan sebelum daging disajikan (Suherman, 1988). Kendati adanya perbedaan antara perlakuan terhadap cita rasa namun pemberian krokot tersebut tidak memberikan efek yang kurang baik terhadap cita rasa daging ayam.

\section{KESIMPULAN}

Subtitusi krokot sampai dengan level 15 $\%$ dalam ransum ayam broiler berpengaruh terhadap cita rasa namun tidak berpengaruh terhadap aroma dan warna daging. Pada level tersebut masih dalam batasan yang normal dan dapat mempertahankan dan meningkatkan organoleptik daging ayam broiler. Dari hasil penelitian ini disarankan untuk melakukan penelitian lanjutan dengan menggunakan tepung krokot pada level lebih tinggi sebagai pembanding untuk mengetahui batasan level krokot dalam ransum ayam broiler terutama terhadap kandungan kolesterol daging ayam.

\section{DAFTAR PUSTAKA}

Amerine, M. A., R. M. Pangborn dan E. B. Roessler. 1965. Principles of Sensory
Evaluation of Food. Academic Press, New York.

Atmomarsono, U. 2004. Upaya Menghasilkan Daging Broiler Aman dan Sehat. Pidato Pengukuhan Jabatan Guru Besar. Fakultas Peternakan Universitas Diponegoro.

Bou, R., F. Guardiola, A. C. Barroeta, dan R. Codony. 2005. Effect of dietary fat sources and zinc and selenium supplements on the composition and consumer acceptability of chicken meat. Poultry Science 84:11291140

Evaniarini, H., Nurliyani, Indratiningsih, and P. Hastuti. 2016. Kestabilan emulsi dan karakteristik sensoris low fat mayonnaise dengan menggunakan kefir sebagai emulsifier replacer. Jurnal Ilmu dan Teknologi Hasil Ternak 11(2):53-59.

Goldberg, E. M., N. Gakhar, D. Ryland, M. Aliani, and Gibson R.A. 2012. Fatty acid profile and sensory characteristics of table eggs from laying hens fed hempseed and hempseed oil. Journal of Food Science 77(4):153-160.

Irawan, D., P. Hariyadi, and H. Wijaya. 2003. The potency of krokot as functional food ingredients. Indonesian Food and Nutrition Progress 10(1):1-12.

Kartikasari, L. R., B. S. Hertanto, I. Santoso dan A. M. P. Nuhriawangsa. 2018. Kualitas fisik daging ayam broiler yang diberi pakan berbasis jagung dan kedelai dengan suplementasi tepung purslane (Portulaca oleracea). Jurnal Teknologi Pangan. 12 (2) : 64-71

Kartikasari, L. R., R. J. Hughes, M. S. Geier, S. E. P. Bastian, M. Makrides, \& R. A. Gibson. 2012. Comparison of omega-3 levels in two strains of broilers and layers fed high alpha linolenic acid diets. In: Proceedings of the World's Poultry Science Association, the 23rd Annual Australian Poultry Science Symposium. Sydney, New South Wales. pp. 237-240.

Mullik, M. L., Y. L. Henuk, \& T. O. D. Dato. 2015. Inklusi Tepung Krokot (Portulaca oleraceae L). dalam Ransum Ayam Broiler Untuk Produksi Daging Rendah Kolesterol dan Kaya Anti-oksidan. Laporan Penelitian Program Studi Ilmu Peternakan Program 
Pasca Sarjana Universitas Nusa Cendana Kupang.

Rashed A. N., Afifi F. U., Shaedah. M., 2004. Investigation Of The Aktive Constituenst of Portulaca Oleracea L. (Portulaceae) Growing In Jordan. Pakistan Journal Of Pharmaceutical Sciences. $17: 37-45$.

Rashed, S., U. Akhter, S. Manohar, \& Z. Sajjad. 2004. Food aid distribution in Bangladesh, FCND briefs 173, International Food Policy Research Institute (IFPRI).

Rowghani, E., M. Arab, Nazifi S and Bakthiari Z. 2007. Effect of canola oil on cholesterol and fatty acid composition of egg-yolk of laying hens. Journal Poultry Science 6(2):111-114.

Soeparno. 1994. Ilmu dan Teknologi Daging. Gadjah Mada University Press, Yogyakarta

Soeparno, 2005. Ilmu dan Teknologi Daging. Gajah Mada University Press, Yogyakarta.

Steel, R. G. D. and J. W. Torrie. 1993. Prinsip dan Prosedur Statistika : Suatu Pendekatan
Biometrik. Terjemahan : B. Sumantri. PT. Gramedia Pustaka Utama, Jakarta.

Suherman, D. 1988. Cara Pemasakan terhadap Rasa Daging Ayam Broiler. Majalah Poultry Indonesia 104: 26-27.

Syahruddin, E. 2000. Pengaruh Berbagai Tingkatan Serat Kasar dalam Ransum Terhadap Kandungan Kolesterol dan Organ Pencernaan Ayam Broiler. Jurnal Peternakan dan Lingkungan 6 (2): 26-30

Tulanggalu, W. M., H. Sutedjo, and G. Maranatha. 2017. Pengaruh Penambahan Tepung Krokot (Portulaca oleracea L) Dalam Ransum Terhadap Kualitas Fisik Daging Ayam Broiler. Jurnal Nukleus Peternakan. 4: 15-21.

Uddin, M. K., A. S. Juraimi, M. S Hossain, M. A. U. Nahar, M. E. Ali, and M.M. Rahman. 2014. Purslane weed (Portulaca oleracea $L)$ a prospective plant source of nutrition, omega-3 fatty acid and antioxidant attributes. Scientific World Journal 14(1):16. 